\title{
Serpens flexibilis gen. nov., sp. nov., an Unusually Flexible, Lactate-Oxidizing Bacterium
}

\author{
ROBERT B. HESPELL \\ Microbiology Division, Department of Dairy Science, University of Illinois, Urbana, Illinois 61801
}

\begin{abstract}
An extremely flexible, motile, rod-shaped bacterium $(0.3$ to 0.35 by 8 to 12 $\mu \mathrm{m})$ was isolated from samples of pond mud. The organism can readily move through media containing $1 \%$ (wt/vol) agar. Only subsurface, spreading growth occurs on media containing less than $1.5 \%$ (wt/vol) agar. In agar media, cells displayed serpentine-like motility and rapidly coiled and uncoiled into a variety of knot forms. The organism possesses a gram-negative type of cell envelope with a peptidoglycan layer containing muramic acid, glucosamine, glutamic acid, diaminopimelic acid, and alanine in a ratio of 1.0/1.0/1.0/1.0/2.0, respectively. The cells possess bacterial flagella which occur both in bipolar tufts (4 to 10 flagella per tuft) and, to a lesser extent, singly over the surface of the cell. The organism only grew aerobically. Among the substrates tested, lactate was the only major energy and carbon source used. Carbohydrates, fatty acids, and amino acids did not support growth. Casein hydrolysate, peptone, and $\mathrm{NH}_{4} \mathrm{Cl}$ were used as nitrogen sources. Although both vitamin mixtures and yeast extract stimulated growth, no vitamins were required for growth. Cell extracts contain high levels of tricarboxylic acid cycle enzyme activities but only trace levels of glycolytic enzyme activities. The guanine-plus-cytosine content of the deoxyribonucleic acid of the organism is $65.8 \mathrm{~mol} \%$ (strain PFR-1, buoyant density). For this organism, apparently previously undescribed, the name Serpens flexibilis gen. nov., sp. nov. is proposed. The type strain of $S$. flexibilis is PFR-1 (=ATCC 29606).
\end{abstract}

In many natural environments, flexible, thin bacteria such as spirilla and spirochetes often constitute a small fraction of the total microbiota. The isolation of these organisms in pure culture is generally difficult as many enrichments invariably become overgrown with other, undesired bacteria. This problem has been overcome in many instances by the use of the selective isolation procedure of Canale-Parola et al. (4). This method is based on selective passage of the desired bacterial cell through a membrane filter of pore size similar to the diameter of the organism. Using this technique, the isolation of many thin spirilla and spirochetes has been accomplished $(1,4,8)$. In the course of using this filter technique to isolate aerobic, free-living spirochetes from natural sources, the author isolated an unusually flexible, thin, rod-shaped bacterium which did not appear to be either a spirillum or a spirochete. This organism was particularly interesting since it displayed a fascinating rapid motility involving complex bending, coiling, and serpentine-like movements when grown in agar media. The present communication describes the studies on the morphology and physiology of this hitherto undes- cribed bacterium, for which the name Serpens flexibilis gen. nov., sp. nov. is here proposed.

\section{MATERIALS AND METHODS}

Bacterial strains. Strains of $S$. flexibilis were isolated by a method similar to that used by Breznak and Canale-Parola (1) for the isolation of free-living facultatively anaerobic spirochetes. The isolation medium included (per $90 \mathrm{ml}$ of distilled water): yeast extract, $0.2 \mathrm{~g}$; peptone, $0.1 \mathrm{~g}$; hay extract, $10 \mathrm{ml}$; and agar, $1.0 \mathrm{~g}$. The hay extract was prepared by boiling $1.0 \mathrm{~g}$ of dry hay in $100 \mathrm{ml}$ of distilled water for 15 min. After cooling, the hay was removed and the boiled mixture was clarified by centrifugation $(8,000$ $\times g, 10 \mathrm{~min}$ ). The $\mathrm{pH}$ of the isolation medium was adjusted to 7.0 before sterilization.

The inoculum was a pond water-mud slurry obtained from the upper few centimeters of sediment. The slurry was filtered through Whatman no. 40 filter paper to remove large particles. The filtrate $(0.1$ to $0.2 \mathrm{ml}$ ) was added to the center of a sterile cellulose filter disk ( $0.45-\mu \mathrm{m}$ pore diameter) placed on the agar surface of a plate of isolation medium. After $12 \mathrm{~h}$ at $30^{\circ} \mathrm{C}$, the filter disk was removed aseptically from the plate, and incubation of the plate was continued for 2 days. The growth of the organism appeared as a subsurface, whitish veil which diffused towards the edge of the plate. The organism was freed from other, 
contaminating bacteria by transferring a small amount of agar taken from the outermost edge of the veil to the surface of a second plate. A pure, cloned culture of the organism was obtained from the veil of growth on the second plate by standard streaking procedures using an isolation medium containing $1.5 \%$ (wt/vol) agar because distinct colony formation occurred on this medium of higher agar concentration. Five strains were isolated in this manner using pond samples collected in California, Illinois, and Massachusetts. Since all strains appeared quite similar in morphology and basic nutritional requirements, only $S$. serpens strain PFR-1 (from a sample of pond sediment collected near Amherst, Mass.) was studied in detail and is described here.

Culture media and nutritional studies. Strain PFR-1 was routinely grown with aeration in a lactate broth (LYPP) consisting of (per $100 \mathrm{ml}$ of distilled water): $60 \%$ sodium lactate syrup, $1 \mathrm{ml}$; yeast extract, $0.3 \mathrm{~g}$; peptone, $0.2 \mathrm{~g}$; and potassium phosphate buffer (pH 7.4), $0.02 \mathrm{M}$ final concentration. The $\mathrm{pH}$ of the medium was adjusted to 7.2 before sterilization. Cells were grown in 1-liter Erlenmeyer flasks containing $250 \mathrm{ml}$ of lactate broth on a rotary shaker operating at 150 to $250 \mathrm{rpm}$. Lactate-agar medium was prepared by adding $1.5 \mathrm{~g}$ of agar per $100 \mathrm{ml}$ of LYPP broth.

In experiments designed to study the vitamin requirements of this strain, the basal medium (LCH) consisted of (per $100 \mathrm{ml}$ of distilled water): $60 \%$ (wt/vol) sodium lactate syrup, $1 \mathrm{ml} ; 1.0 \mathrm{ml}$ of trace minerals (8); and potassium phosphate buffer ( $\mathrm{pH}$ 7.4), $0.04 \mathrm{M}$ final concentration. The medium used to study the utilization of carbon compounds by $S$. flexibilis was similar in composition to LYPP broth with the exception that the yeast.extract concentration was reduced to $0.05 \mathrm{~g}$ per $100 \mathrm{ml}$ of medium.

In growth and nutritional experiments, the organism was grown in 250-ml Erlenmeyer flasks, each containing $50 \mathrm{ml}$ of medium. The flasks were equipped with side arms, and growth yields were determined turbidimetrically by means of a Klett-Summerson photoelectric colorimeter equipped with a $660-\mathrm{nm}$ filter. Colorimeter readings were converted to cell numbers by using a standard curve relating the reading to direct cell counts. Unless indicated otherwise, an incubation temperature of $30^{\circ} \mathrm{C}$ was used for all growth experiments. To minimize any nutritional carryover effects, the growth of a culture was measured only after at least a $10^{6}$ serial dilution of the initial inoculum had been established.

Microscopy. Cells for electron or phase-contrast microscopy were grown in LYPP broth with aeration and harvested in the exponential phase of growth. Samples for negative staining and thin sectioning were examined as previously described (8) or as described by Silva and Sousa (17). A Zeiss GFL phase-contrast microscope was used for light-microscope observations. Photographs were taken on Kodak Tri-X film using a Zeiss C-35 camera attachment.

Determination of $\mathbf{G}+\mathrm{C}$ content of the DNA. Cells were suspended in a solution ( $\mathrm{pH} 7.5$ ) containing $0.1 \mathrm{M} \mathrm{NaCl}$ and $0.1 \mathrm{M}$ sodium ethylenediaminetetraacetate. The cells were lysed with sodium dodecyl sulfate (SDS; $1 \%$, wt/vol) and deproteinized with phenol (14). The guanine-plus-cytosine $(\mathrm{G}+\mathrm{C})$ content of the deoxyribonucleic acid (DNA) was determined by estimating the buoyant density in cesium chloride (13).

Isolation of peptidoglycan. Approximately $85 \mathrm{~g}$ (wet wt) of frozen cell paste was rapidly thawed in 30 $\mathrm{ml}$ of triethanolamine buffer $(0.1 \mathrm{M}, \mathrm{pH} 7.6)$ containing deoxyribonuclease $(10 \mu \mathrm{g} / \mathrm{ml})$ and ribonuclease $(5$ $\mu \mathrm{g} / \mathrm{ml}$ ). A solution of boiling $20 \%$ (wt/vol) SDS was added slowly with stirring to a final SDS concentration of $4 \%(\mathrm{wt} / \mathrm{vol})$. The resulting clear, dark red mixture was stirred for $20 \mathrm{~min}$ at $70^{\circ} \mathrm{C}$. After cooling, the mixture was centrifuged $\left(100,000 \times g, 60 \mathrm{~min}, 22^{\circ} \mathrm{C}\right)$, the pellets were suspended in $30 \mathrm{ml}$ of the triethanolamine buffer, and the above-mentioned hot SDS treatment was repeated twice more. The final pellets were freed of SDS by six successive washes with distilled water, each wash followed by centrifugation $(100,000$ $\times g, 30 \mathrm{~min}, 22^{\circ} \mathrm{C}$ )

The washed pellets, viscous and slightly opaque, were suspended in $95 \mathrm{ml}$ of $0.05 \mathrm{M}$ tris(hydroxymethyl)aminomethane-0.01 $\quad \begin{array}{lll}\mathrm{M}_{2} & \mathrm{CaCl}_{2}\end{array}$ buffer ( $\mathrm{pH} 8.1$ ), and $2.5 \mathrm{ml}$ of trypsin $(4 \mathrm{mg} / \mathrm{ml})$ in $10^{-3} \mathrm{M} \mathrm{HCl}$ was added. About $1 \mathrm{ml}$ of $\mathrm{CHCl}_{3}$ was added and the mixture was incubated $\left(30^{\circ} \mathrm{C}\right)$ for 14 h. This trypsin-treated mixture was then subjected to two successive hot SDS treatments, and the final pellets were washed free of SDS as described above. The final isolated material was clear and gelatinous and dispersed very slowly in water.

Enzyme activities. Cells in the logarithmic phase of growth were harvested by centrifugation of LYPP cultures. Cell suspensions were prepared in $0.1 \mathrm{M} \mathrm{N}-2$ hydroxyethylpiperazine- $N^{\prime}$-2-ethanesulfonic acid (HEPES) $-10^{-3} \mathrm{M}$ dithiothreitol buffer ( $\mathrm{pH} 7.5$ ) after being washed twice in this buffer. Cells were disrupted by two passaged through a French pressure cell $(2,000$ $\mathrm{lb} / \mathrm{in}^{2}, 5^{\circ} \mathrm{C}$ ), and large cell debris was removed by centrifugation $\left(27,000 \times \mathrm{g}, 15 \mathrm{~min}, 5^{\circ} \mathrm{C}\right)$. Soluble-enzyme activities (supernatant liquid) were separated from particulate-enzyme activities (pellet) by centrifugation $\left(144,000 \times \mathrm{g}, 90 \mathrm{~min}, 4^{\circ} \mathrm{C}\right)$ of the cell extract. Cell enzyme activities were measured by previously described methods $(5,9)$.

Respiration and manometry. Oxygen consumption by cell suspensions was measured by the use of either an oxygen electrode cell or conventional Warburg techniques (18) as described previously (10). The cell suspensions were prepared in either $0.1 \mathrm{M}$ triethanolamine or HEPES buffer ( $\mathrm{pH} \mathrm{7.2)} \mathrm{after} \mathrm{being}$ washed twice by centrifugation in the buffer.

Other experimental procedures. Tests for catalase and nitrite production as well as for other routinely determined characters were performed as described by Conn et al. (6). Chemotaxis experiments involved procedures similar to those employed with spirochetes (2). Metabolic by-products in culture media after growth were analyzed by gas-liquid chromatography of butyl esters of short-chain fatty acids (15)

\section{RESULTS}

Isolation and morphology. S. flexibilis strain PFR-1 formed a subsurface, spreading veil of growth in agar media similar to that commonly observed with spirochetes. Phasecontrast-microscopy observation of a small piece of agar excised from the leading edge of the 

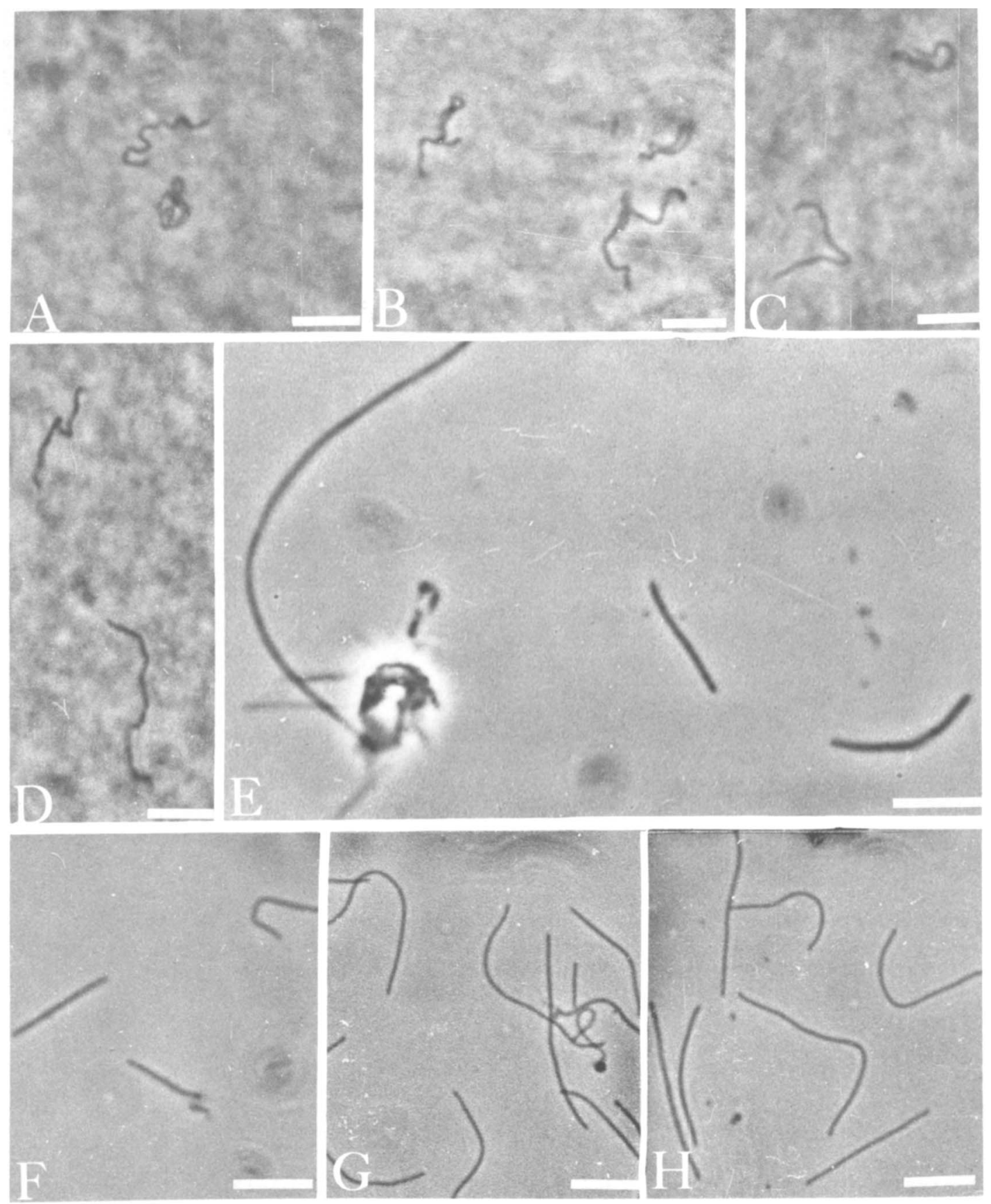

FIG. 1. Living cells of Serpens flexibilis PFR-1. Wet-mount preparations, phase contrast. Cells in agar pieces excised from subsurface, spreading growth $(A$ to $D)$ displayed rapid motion with bending, lashing, and serpentine-like movements. Cells rapidly reversed themselves between coiled and uncoiled forms $(A)$. In liquid menstrua ( $E$ to $H$ ), logarithmic-phase cells $(F$ and $H$ ) showed straight-line movements with flexing of the cell body. Stationary-phase cells often clumped (E) and had protuberances (G). Marker bars represent $3.0 \mu \mathrm{m}$. 
growth veil revealed the presence of unusually flexible motile rods measuring approximately 0.3 by $10 \mu \mathrm{m}$ (Fig. 1A to D). The organism moved very rapidly and displayed a variety of movements marked by a notably furious lashing and bending of the cells. A serpentine-like motility was commonly seen. In addition, the organism was frequently observed to quickly coil into a knot !ike conformation (Fig. 1A) and then, with equa rapidity, to uncoil into a linear form. In liquir menstrua, the cells displayed less dramatic movement. The organism moved rapidly with reversals in direction along a straight-line axis. During this movement, an overall gentle flexing of the cell (Fig. 1, F-H) occurred with the distal or trailing tip of the cell vibrating intensely. This vibration was particularly pronounced with cells in the logarithmic growth phase; these cells measured 0.3 to 0.4 by 10 to $12 \mu \mathrm{m}$ (Fig. 1F). In addition, it was noted that cells in liquid menstrua often traveled straight-line distances of approximately 60 to $80 \mu \mathrm{m}$ and then momentarily ceased all movement before either moving on in the same direction or reversing direction. No tumbling-type of movement was ever observed. Cells in lag or early stationary growth phase tended to be much longer (approximately 0.3 to 0.4 by 16 to $25 \mu \mathrm{m}$ [Fig. 1E]). Spherical bodies similar to those described for spirochetes (1) were present in cultures, where they occurred either free or attached to cells (Fig. 1G). Clumps of entwined cells (Fig. 1E), cells appearing partially lysed, and spherical bodies were more numerous when cultures were in the stationary growth phase.

The cells of $S$. flexibilis PFR-1 tended to be quite fragile since much cell lysis and loss of motility occurred when cell pellets were suspended with agitation in either distilled water or the numerous buffers tested. Minimal lysis and loss of motility were observed with cell suspensions prepared in 0.1 M HEPES or triethanolamine buffers ( $\mathrm{pH} 7.0$ ) containing $10^{-3} \mathrm{M}$ each $\mathrm{CaCl}_{2}$ and $\mathrm{MgCl}_{2}$; transmission electron microscopy of cell suspensions prepared in these buffers usually revealed cells with a wrinkled cell envelope and 4 to 10 flagella attached in close proximity at one or both ends of a cell (Fig. 2). However, cells were frequently observed which also had a few additional flagella attached randomly along the cell body. Numerous unattached free flagella and flagella fragments were always seen even when gentle preparative techniques were used. The flagella had a constant waveform with an amplitude of approximately $0.29 \mu \mathrm{m}$ and a wavelength of approximately 0.88 $\mu \mathrm{m}$ and were typically 1.5 to 3.0 cell lengths (approximately 15 to $30 \mu \mathrm{m}$ ) long. Some free flagella possessed a hooked end and a disk struc- ture similar to that observed with other bacterial flagella (7).

Electron microscopy of thin sections of cells revealed a gram-negative pattern of cell wall structure (Fig. 3), although due to the fragile nature of the cells, some general cellular disorganization was always evident. The cell wall was composed of a double-track outer membrane layer with appearance and dimensions equivalent to those of the underlying cytoplasmic membrane. A distinct peptidoglycan layer was not generally evident. At various points along the cell length, the cytoplasmic membrane invaginated into the cytoplasm to form intracytoplasmic structures which appeared to connect to the cytoplasmic membrane on the opposite cell side (Fig. 3). Fibrillar nucleic acid material dominated the central portion of the cytoplasm whereas ribosome-like structures were more prevalent in the cytoplasmic region near the cell membrane.

The extreme flexibility and the absence of a clearly distinguishable peptidoglycan layer in thin sections of cells suggested that perhaps $S$. flexibilis PFR-1 lacked this cell wall layer. A clear, but slightly opaque, material was isolated (see Materials and Methods) from cells after SDS treatments and was freed of protein by digestion with trypsin. The isolated material (approximately $0.6 \%$ of the cell dry weight) was clear, gelatinous, colloidally dispersed, and sedimentable $(144,000 \times g, 30 \mathrm{~min})$. Electron-microscopy observations indicated that the isolated material consisted of baglike structures about 0.4 by 10 to $12 \mu \mathrm{m}$. Treatment of the isolated material with egg-white lysozyme $(10 \mu \mathrm{g} / \mathrm{ml}$, $37^{\circ} \mathrm{C}, 20 \mathrm{~min}$ ) resulted in a complete loss of these structures and sedimentable $(144,000 \times g$, $3 \mathrm{~h})$ material.

The isolated wall material was acid hydrolyzed, and the hydrolysates were subjected to amino acid analysis (Table 1). The major constituents present were muramic acid, glucosamine, glutamic acid, diaminopimelic acid, and alanine in an approximately 1.0/1.0/1.0/1.0/2.0 ratio, respectively. The slight differences observed in this ratio can be accounted for by the instability of the amino sugars under the hydrolysis conditions as indicated by the differences in the 8- and 16-h samples and the $\mathrm{NH}_{3}$ found. The analysis showed that only trace levels of additional amino acids were also present. The trace levels of amino acids found indicate that the peptidoglycan cross-linking is direct and lacks amino acid bridges. The data show that S. flexibilis PFR-1 does in fact possess a peptidoglycan cell wall layer.

Colony characteristics. Aerobic colonies on media containing 1.8 to $2.0 \%$ (wt/vol) agar were 


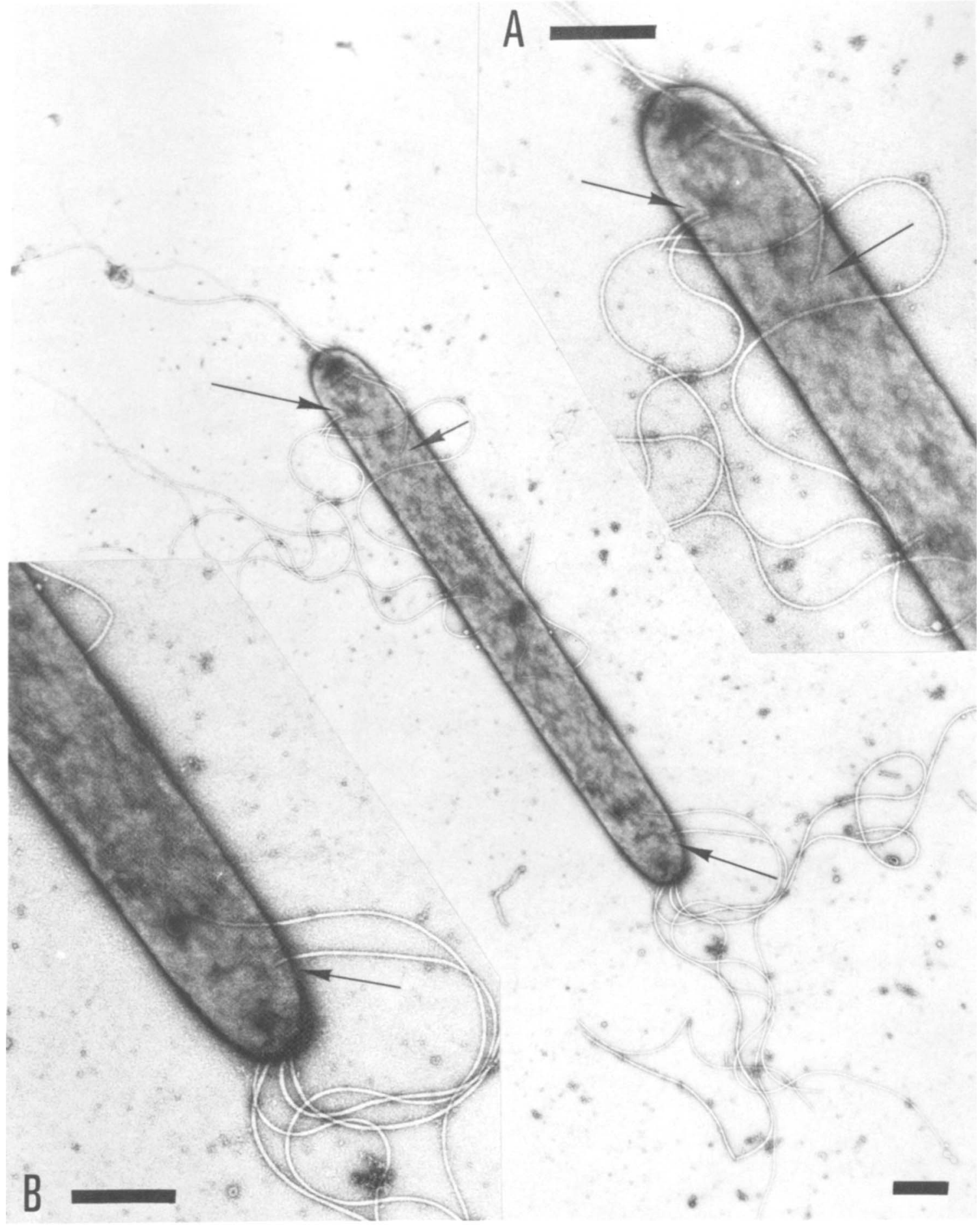

FIG. 2. Transmission electron micrograph of S. flexibilis PFR-1 cells. The inserts (A and B) are higher magnifications of the ends of the same cell stained with phosphotungstic acid. Although the overall cell shape has been preserved, some flagella have detached, and an aggregate of four flagella remains at one end of the cell. Several laterally inserted flagella are present, and their insertion points (arrows) are more clearly evident in the inserts. The marker bars represent $0.25 \mu \mathrm{m}$. 


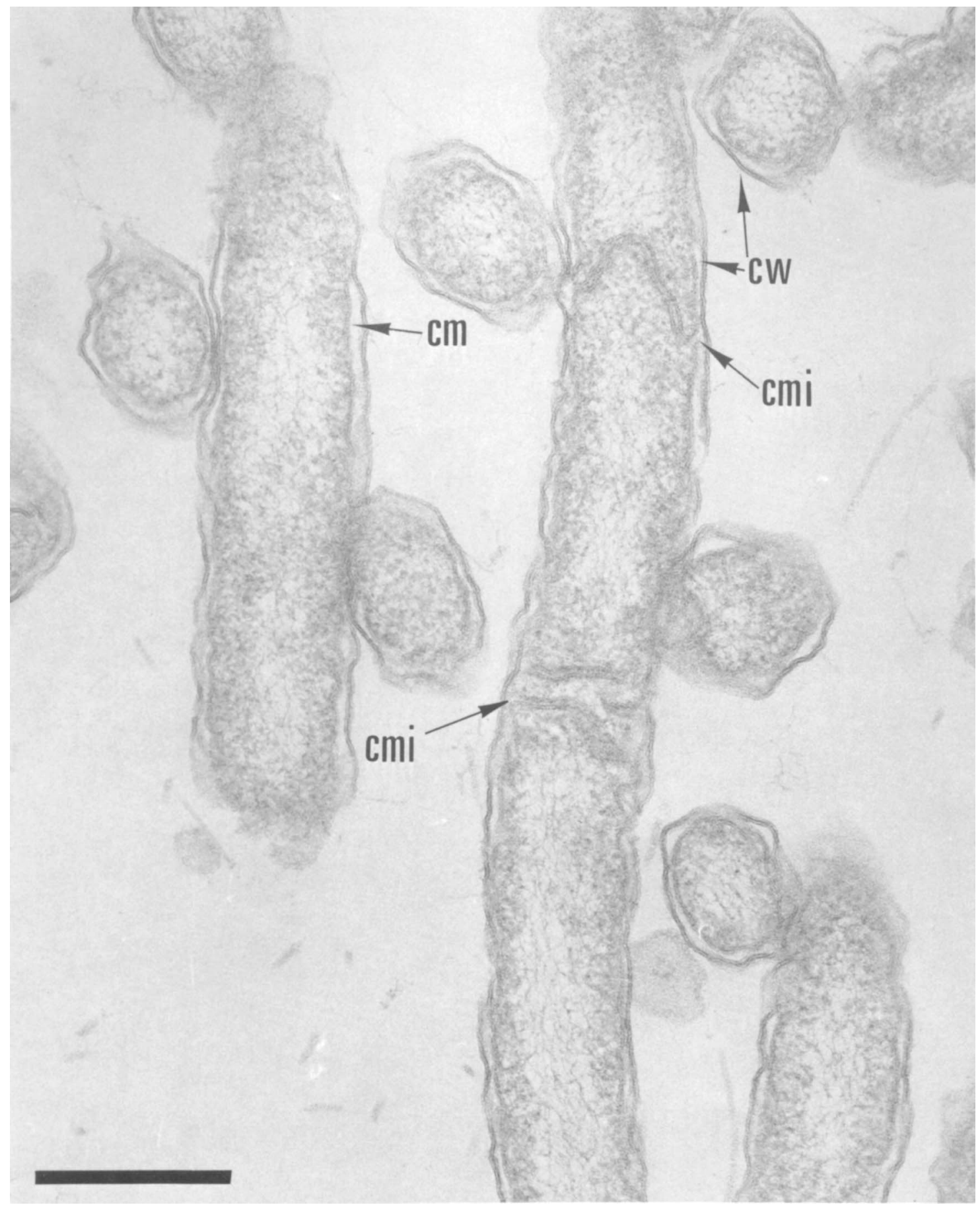

FIG. 3. Transmission electron micrograph of a thin section of S. flexibilis PFR-1 cells. The cytoplasmic membrane (cm) appears as a double-track layer. The cell wall layer (cw) is similar in appearance and thickness to the cytoplasmic membrane. At various points, cytoplasmic-membrane invaginations (cmi) are seen and appear to connect the cytoplasmic membrane on opposite sides of the cell. Marker bar represents $0.5 \mu \mathrm{m}$. 
TABLE 1. Amino acid analysis of acid hydrolysates of peptidoglycan purified from Serpens flexibilis strain PFR-1 ${ }^{a}$

\begin{tabular}{lcc}
\hline \multicolumn{1}{c}{$\begin{array}{c}\text { Compound present in } \\
\text { peptidoglycan hydrol- }\end{array}$} & $\begin{array}{c}\text { Amt }(\mu \mathrm{mol} / \mu \mathrm{mol} \text { of diami- } \\
\text { nopimelic acid) of com- } \\
\text { pound present in: }\end{array}$ \\
\hline Glucosamine & $\begin{array}{c}\text { 8-h hydrol- } \\
\text { ysate }\end{array}$ & $\begin{array}{c}\text { 16-h hy- } \\
\text { drolysate }\end{array}$ \\
Muramic acid & 0.824 & 0.716 \\
Alanine & 0.861 & 0.684 \\
Glutamic acid & 1.969 & 1.941 \\
Diaminopimelic acid & 1.000 & 0.988 \\
Ammonia & 1.000 & 1.000 \\
Aspartic acid & 0.268 & 0.489 \\
Threonine & 0.015 & 0.013 \\
Serine & 0.006 & 0.006 \\
Glycine & 0.017 & 0.002 \\
Isoleucine & 0.049 & 0.049 \\
Leucine & 0.001 & 0.002 \\
Phenylalanine & 0.004 & 0.001 \\
Histidine & 0.003 & 0.001 \\
Lysine & 0.004 & 0.004 \\
\hline
\end{tabular}

${ }^{a}$ Peptidoglycan preparations were purified (see Materials and Methods), and 1-mg amounts were hydrolyzed with $6 \mathrm{~N} \mathrm{HCl}$ at $100^{\circ} \mathrm{C}$ under argon. Amino acid analysis of the hydrolysates was carried out by use of a Spinco model 120 amino acid analyzer.

$3.6 \mathrm{~mm}$ in diameter $\left(30^{\circ} \mathrm{C}, 36 \mathrm{~h}\right)$, off-white to cream colored, and round with filamentous edges. Colonies grew primarily on the agar surface with only slight growth within the agar. On media containing $1.5 \%(\mathrm{wt} / \mathrm{vol})$ or less agar, the discreteness of colonies decreased with decreasing levels of agar. At 1.0 to $1.2 \%$ (wt/vol) agar, colonies were 0.5 to $1.0 \mathrm{~mm}$ in diameter with a subsurface (1 to $3 \mathrm{~mm}$ deep) veil of growth which increased in diameter with incubation. Only spreading subsurface growth was observed with media containing less than $0.8 \%$ (wt/vol) agar. The subsurface growth initially consisted of a dense circular ring of cells which constantly increased in diameter leaving behind a veil of less dense growth. Cell growth continued within the circumscribed veil with another dense ring of growth occurring first in the center of the veil and gradually progressing outward towards the edge of the veil. This growth pattern continued with the development of another one or two similar rings. Concomitant with the increased cell numbers, growth became less subsurface and extended to, but not above, the agar surface. The subsurface growth suggested that $S$. flexibilis PFR-1 preferred oxygen tensions less than atmospheric. However, no growth of the organism occurred in any liquid or agar media when the cultures were incubated anaerobically under argon or nitrogen, even with nitrate or sulfate included in the media.
Experiments were conducted to determine whether the concentration of lactate (the major energy substrate for $S$. flexibilis PFR-1, see below) in the growth medium affected the migration of cells through the agar gel. Approximately $0.05 \mathrm{ml}$ of cells from a mid-logarithmicphase culture were deposited in a small well in the center of LYPP agar $(0.8 \%, \mathrm{wt} / \mathrm{vol})$ medium plates containing various levels of lactate. Examination of all plates after $60 \mathrm{~min}$ at $25^{\circ} \mathrm{C}$ showed that the liquid had been absorbed from the wells and each well had a visible concentric growth ring around it. During subsequent incubation, the diameter of this ring was measured at various time intervals. The data showed that, in the absence of added lactate, the rate of ring diameter increase was $2.0 \mathrm{~mm} / \mathrm{h}$. This rate increased to a maximum of only $2.4 \mathrm{~mm} / \mathrm{h}$ when lactate was added over the range of $3 \times 10^{-4} \mathrm{M}$ to $90 \times 10^{-4} \mathrm{M}$. Similar results were observed with plates incubated at $30^{\circ} \mathrm{C}$, but the migration rates were faster: $2.5 \mathrm{~mm} / \mathrm{h}$ in the absence of added lactate and $3.1 \mathrm{~mm} / \mathrm{h}$ with $9 \times 10^{-4} \mathrm{M}$ lactate.

Nutrition. S. flexibilis PFR-1 was rather limited with regard to the compounds it could utilize as energy sources, for only lactate markedly stimulated growth over the low-level growth supported by the yeast extract-peptone (Table 2 ). Acetate and $\alpha$-ketoglutarate also stimulated growth, but the growth rates and final growth yields were greatly reduced. Glucose and a few disaccharides marginally stimulated growth, whereas many other compounds tested did not.

In a basal medium (LCH) containing nitrate or nitrite as a nitrogen source, no growth was

TABI.E 2. Utilization of carbon compounds by Serpens flexibilis PFR $1^{a}$

\begin{tabular}{|c|c|}
\hline $\begin{array}{l}\text { Compound added to modified LYPP } \\
\text { broth }\end{array}$ & $\begin{array}{c}\text { Yield } \\
\left(\text { cells } / \mathrm{ml} \times 10^{7}\right)\end{array}$ \\
\hline None & $2.0-6.0$ \\
\hline Sodium lactate ........... & 700.0 \\
\hline Potassium $\alpha$-ketoglutarate & 60.0 \\
\hline Sodium acetate $\ldots \ldots \ldots$ & 40.0 \\
\hline Potassium pyruvate & 20.0 \\
\hline $\begin{array}{l}\text { D-Glucose, D-galactose, trehalose, su- } \\
\text { crose, maltose, cellobiose, or orotic } \\
\text { acid } \ldots \ldots \ldots \ldots \ldots \ldots \ldots\end{array}$ & $10-15$ \\
\hline
\end{tabular}

a The organism was grown in modified LYPP broth (see Materials and Methods) in which the yeast extract was reduced to $0.05 \%$ (wt/vol), the lactate was deleted, and the indicated compound was added to a final concentration of $0.3 \%$ (wt/vol). The initial inoculum was approximately $10^{5} \mathrm{cells} / \mathrm{ml}$ (final concentration). Compounds not supporting growth include sodium citrate, sodium succinate, ethanol, allantoin, uric acid, Tween 60, Tween 80, D-mannose, L-rhamnose, lactose, raffinose, dextrin, inulin, D-ribose, glycerol, mannitol, sorbitol, and dulcitol. 
observed. S. flexibilis PFR-1 grew slowly and with low cell yields in $\mathrm{LCH}$ medium containing no added vitamins and $\mathrm{NH}_{4} \mathrm{Cl}$ as a nitrogen source (Table 3). A dramatic increase in both growth rates and cell yields occurred when casein hydrolysate, peptone, or yeast extract was added to $\mathrm{LCH}$ medium as a nitrogen source provided lactate was also included in the medium. After growth on these latter media, significant levels of $\mathrm{NH}_{3}$ (5 to $12 \mathrm{mM}$ ) were detected, suggesting that some of the added amino acids had been catabolized. Maximal mass doubling times on the order of 15 to $20 \mathrm{~min}$ and cell yields of about $10^{10}$ cells $/ \mathrm{ml}$ were obtained on $\mathrm{LCH}$ medium containing both yeast extract and peptone. Although $S$. flexibilis PFR-1 did not require vitamins for growth, in all cases the addition of a vitamin mixture to a medium stimulated growth rates and cell yields (Table 3 ).

S. flexibilis PFR-1 would not grow on media having an initial $\mathrm{pH}$ below 5.8. Maximal growth occurred with LYPP and LCH media when the initial $\mathrm{pH}$ was 6.8 to 7.2 . After maximal growth, the LYPP medium usually had a $\mathrm{pH}$ of 8 to 9 and of 9 to 11 if the phosphate buffer was deleted. Cell yields of greater than $10^{10}$ cells $/ \mathrm{ml}$ could be obtained with LYPP medium by increasing the phosphate buffer concentration to $0.04 \mathrm{M}$ and periodically adding $\mathrm{HCl}$ to the cul-

TABLE 3. Effects of organic supplements on mass doubling times and growth yields of Serpens flexibilis PFR-1

\begin{tabular}{|c|c|c|c|}
\hline Additions $^{a}$ & $\begin{array}{l}\text { Vita- } \\
\text { mins }^{h}\end{array}$ & $\begin{array}{l}\text { Maximal } \\
\text { doubling } \\
\text { times (h) }\end{array}$ & $\begin{array}{c}\text { Growth } \\
\text { yields } \\
\text { (cells } / \mathrm{ml} \\
\times 10^{9} \text { ) } \\
\end{array}$ \\
\hline \multirow[t]{2}{*}{ None } & + & $\mathrm{NG}^{c}$ & $\mathrm{NG}$ \\
\hline & - & NG & NG \\
\hline \multirow[t]{2}{*}{$\mathrm{NH}_{4} \mathrm{Cl}$} & + & 2.10 & 1.5 \\
\hline & - & $\mathrm{ND}^{r}$ & 1.4 \\
\hline \multirow{2}{*}{$\begin{array}{l}\text { Vitamin-free casein hy- } \\
\text { drolysate (acid) }\end{array}$} & + & 0.40 & 5.5 \\
\hline & - & ND & 5.7 \\
\hline \multirow{2}{*}{$\begin{array}{l}\text { Vitamin-free casein hy- } \\
\text { drolysate (enzyme) }\end{array}$} & + & 0.45 & 3.9 \\
\hline & - & ND & 3.2 \\
\hline \multirow[t]{2}{*}{ Peptone } & + & 0.50 & 2.8 \\
\hline & - & 0.60 & 1.8 \\
\hline \multirow[t]{2}{*}{ Yeast extract } & + & 0.35 & 4.6 \\
\hline & - & 0.40 & 3.3 \\
\hline $\begin{array}{l}\text { Peptone and yeast ex- } \\
\text { tract }\end{array}$ & - & 0.26 & 8.4 \\
\hline
\end{tabular}

${ }^{a}$ The organism was grown at $30^{\circ} \mathrm{C}$ in a basal salts medium ( $\mathrm{LCH}$, see Materials and Methods) with the indicated supplements $(0.4 \%$ [wt/vol] final concentration). The initial inoculum was $10^{6}$ cells $/ \mathrm{ml}$ (final) and was obtained from a culture grown on LCH medium supplemented with $\mathrm{NH}_{4} \mathrm{Cl}$. Growth was monitored until cell lysis began as indicated by microscopic observations and by decreases in optical density.

${ }^{b}$ Vitamin mixture containing thiamine, niacin, para-aminobenzoic acid, biotin, folic acid, riboflavin, pyridoxal phosphate, and vitamin $B_{12}$ was added to give a final growth medium concentration of $10^{-4} \%$ (wt/vol) for each vitamin

" Abbreviations: ND, not determined; NG, no growth. ture to lower the $\mathrm{pH}$. The organism grew well over the range of 20 to $27^{\circ} \mathrm{C}$, and highest growth yields were obtained at 28 to $33^{\circ} \mathrm{C}$. No growth occurred at 10 or at $45^{\circ} \mathrm{C}$.

Physiology and metabolism. The $\mathrm{QO}_{2}$ (microliters of $\mathrm{O}_{2}$ consumed $/ 10^{10}$ cells per hour) of washed $S$. flexibilis PFR-1 cell suspensions incubated in the presence of a number of individual compounds was measured. Such suspensions had an endogenous $\mathrm{Q}_{\mathrm{o}_{2}}$ ranging between 4.8 and 5.5 and an RQ (microliters of $\mathrm{CO}_{2}$ released per microliters of $\mathrm{O}_{2}$ consumed) ranging from 0.69 to 0.78 . Of the individual compounds tested (listed in Table 2), only sodium lactate caused large increases in the $\mathrm{QO}_{2}$ of cell suspensions. An average $\mathrm{QO}_{2}$ of 61.6 and an average $\mathrm{RQ}$ of 1.56 were typically found with cell suspensions incubated with sodium lactate. When cell suspensions were prepared in buffer and incubated with $\left[U-{ }^{14} \mathrm{C}\right]$ lactate, approximately 88 to $93 \%$ of the lactate degraded was catabolized to $\left[{ }^{14} \mathrm{C}\right]$ $\mathrm{CO}_{2}$, and only trace amounts were incorporated into cell material. However, after growth on LYPP medium containing $\left[U^{14} \mathrm{C}\right]$-labeled sodium lactate $(0.005 \mathrm{M} ; 37,000 \mathrm{cpm} / \mathrm{ml})$, only about 55 to $65 \%$ of the initial radioactivity was present in the respired $\mathrm{CO}_{2}$ and 25 to $30 \%$ was incorporated into cell material. Analysis of the LYPP medium after $S$. flexibilis PFR-1 growth indicated only trace amounts of formic and acetic acids as short-chain fatty acid end products from lactate metabolism.

Enzyme activities. Cell extracts of S. flexibilis PFR-1 contained high levels of enzyme activities associated with the tricarboxylic acid cycle (Table 4) but contained only trace levels of enzyme activities of the Embden-Meyerhof

TABLE 4. Enzyme activities in cell extracts of Serpens flexibilis PFR-1

\begin{tabular}{|c|c|}
\hline Enzyme & Sp act ${ }^{a}$ \\
\hline Hexokinase . . . . . . . . . . . . & 27.5 \\
\hline Glucose-6-phosphate dehydrogenase & 21.9 \\
\hline 6-Phosphogluconate dehydrogenase & 20.0 \\
\hline Glucose-6-phosphate isomerase . . . & 23.8 \\
\hline Phosphofructokinase $\ldots \ldots \ldots \ldots$ & 20.2 \\
\hline Fructose-1,6-diphosphate aldolase & 21.0 \\
\hline $\begin{array}{l}\text { Glyceraldehyde-3-phosphate dehydrogen- } \\
\text { ase }\end{array}$ & 23.5 \\
\hline Triose phosphate isomerase $\ldots \ldots \ldots \ldots$ & 20.7 \\
\hline Pyruvate kinase $\ldots \ldots \ldots$ & 28.0 \\
\hline Lactic acid dehydrogenase & 331.0 \\
\hline Citrate synthase $\ldots \ldots \ldots$ & $126.0(39.8)^{b}$ \\
\hline Isocitrate dehydrogenase $\ldots .$. & $925.0(324.0)$ \\
\hline$\alpha$-Ketoglutarate dehydrogenase $\ldots \ldots \ldots$ & $105.0(458.0)$ \\
\hline Malate dehydrogenase $\ldots \ldots \ldots \ldots \ldots$ & $10.0(321.0)$ \\
\hline
\end{tabular}

${ }^{a} \Delta$ Micromoles of substrate per minute per milligram of protein $\times 10^{3}$, as measured with soluble fraction.

${ }^{b}$ Numbers in parentheses are $\Delta$ micromoles of substrate per minute per milligram of protein $\times 10^{3}$, as measured with particulate fraction. 
and hexose monophosphate pathways. A large amount of lactic acid dehydrogenase (LDH) enzyme activity was found in extracts. About a threefold-higher $\mathrm{LDH}$ activity was observed with L-lactic acid as a substrate as compared to D-lactic acid. In the absence of added substrates, low levels of reduced pyridine-nucleotide-oxidizing activities were detected. More than $90 \%$ of these activities and of the $\alpha$-ketoglutarate and malate dehydrogenase activities was associated with the particulate fraction. The majority ( 70 to $75 \%$ ) of the isocitrate dehydrogenase was found in the soluble cell-extract fraction, which also contained all of the other enzyme activities assayed.

DNA base composition. The moles percent $\mathrm{G}+\mathrm{C}$ in the DNA of $S$. flexibilis PFR-1 was determined by $\mathrm{CsCl}$ buoyant density analyses. The density of the DNA of $S$. flexibilis PFR-1 was $1.725 \mathrm{~g} / \mathrm{cm}^{3}$, which corresponded to a $\mathrm{G}+\mathrm{C}$ content of $65.8 \mathrm{~mol} \%$.

\section{DISCUSSION}

A distinguishing characteristic of $S$. flexibilis PFR-1 is its rapid serpentine-like motility in which extreme flexing and bending of the cell body occur. Similar to observations commonly made with other highly flexible, motile bacteria such as spirochetes, these cell movements were most apparent with $S$. flexibilis PFR-1 cells grown in agar-containing media. Recently, it has been demonstrated that the migration through agar gels by the free-living spirochete Spiro. chaeta aurantia is a chemotactic response to carbohydrates (2). In addition, the migration rate of this spirochete was shown to be a function of the carbohydrate (growth substrate) concentration in the medium. With $S$. flexibilis PFR1 , the observed migration rates in agar media did not appear to be directly proportional to the lactate concentration, although the addition of lactate increased the migration rates some 15 to $20 \%$. This suggests that S. flexibilis PFR-1 might be chemotactic either positively towards lactate or negatively towards altered environmental conditions in the agar created by the catabolism of lactate. This possibility of negative chemotaxis seems less likely since, with continued incubation, secondary growth rings formed and migrated with equal rapidity in the area circumscribed by the initial growth ring. Regardless of whether $S$. flexibilis PFR-1 is chemotactic towards lactate, it is clear that this organism can migrate through agar gels considerably faster than can spirochetes. At $30^{\circ} \mathrm{C}$ in media containing $0.5 \%$ (wt/vol) agar, the maximal observed migration rates are approximately $0.5 \mathrm{~mm} / \mathrm{h}$ and $0.8 \mathrm{~mm} / \mathrm{h}$ for Spirochaeta auran- tia (calculated from Fig. 8 of reference 2) and for Spirochaeta litoralis (R. B. Hespell, unpublished data), respectively. Under similar conditions, S. flexibilis PFR-1 migrated at approximately $4 \mathrm{~mm} / \mathrm{h}$, and even in $0.8 \%$ (wt/vol) agarcontaining media, migration rates were reduced only to 1.5 to $2.5 \mathrm{~mm} / \mathrm{h}$. In addition, $S$. flexibilis can maintain translational movement in liquid menstrua at viscosities which completely inhibit movement by $S$. aurantia (E. Canale-Parola, personal communication). These results are of a limited nature but are consistent with the qualitative conclusion from microscopic observations that, in general, $S$. flexibilis PFR-1 appears to have substantially more flexibility and rapidity in cell-body movements than many of the small, thin spirochetes.

The unique movements commonly displayed by $S$. flexibilis PFR-1 growing in agar media suggested that the organism's cell envelope might have some unusual properties. Consistent with the staining properties of whole cells, electron microscopy of thin sections of cells revealed that $S$. flexibilis PFR-1 possesses a gram-negative type of cell envelope. In thin sections, the cell envelope appeared to consist of a doubletrack cytoplasmic membrane, a periplasmic region, and an outer membrane layer similar in appearance to the cytoplasmic membrane. Although specimens were prepared using conditions which permit the peptidoglycan layer to be observed (17), this layer was not clearly seen in many thin sections as a result of cellular disorganization during preparation of these extremely fragile cells for microscopy. However, bag-shaped structures which were degraded by lysozyme and which had the chemical composition (Table 1) of a peptidoglycan typical of gramnegative bacteria (16) were isolated from $S$. flexibilis PFR-1 cells. Thus, the extreme flexibility of this organism cannot be explained by the absence of a peptidoglycan layer in its cell envelope. Further elucidation of the chemical linkages and composition of the $S$. flexibilis PFR-1 peptidoglycan and of the outer membrane may reveal some bases for this organism's extreme cell wall flexibility.

S. flexibilis PFR-1 possesses bacterial flagella, as shown by electron microscopy (Fig. 2). The great ease with which flagella detached from the cells, even with gentle preparatory techniques, precluded an accurate determination of the flagellar arrangement and number. Nevertheless, the organism seemed to have a flagellar arrangement in which there are at least 4 to 10 flagella clustered at both cell ends and a lesser indeterminate number of flagella located laterally along the cell. Cells frequently appeared 
to retain terminally located flagella whereas the lateral flagella were lost. Most preparations showed numerous free unattached flagella, some of which occasionally possessed a basal insertion structure. Thus, on morphological grounds, the flagella of S. flexibilis PFR-1 are typical bacterial flagella. The question then remains as to how these long flagella (10 to $30 \mu \mathrm{m})$ are coordinated so as to produce the rapid, complex coiling and serpentine-like movements observed with cells in agar media (Fig. 1A to D).

In addition to its motility, another unusual, if not unique, aspect of $S$. flexibilis PFR-1 is its overall physiology. The organism has no specific vitamin requirements and apparently grows only with lactate as a carbon and energy source, but marginal cell yields are also observed with acetate or $\alpha$-ketoglutarate. The organism does not grow anaerobically, but its predilection for subsurface growth in agar suggests that the organism prefers oxygen tensions less than atmospheric. The type of natural environment from which $S$. flexibilis can be readily isolated is the upper few centimeters of the sediment of eutrophic ponds. This environment would be expected to have low oxygen tensions and substantial organic matter which would be fermented by the indigenous microflora. This microflora would include facultative anaerobes and anaerobes, but it would probably lack highly oxygensensitive anaerobes such as desulfovibrios and methanogens. As is commonly the case with many bacterial fermentations, the fermentations in this sediment could be expected to produce some acetate and lactate as end products which $S$. flexibilis could use for growth. In this environment, this organism's preference for lactate may be of a selective advantage since this compound may be more' readily available than sugars which would be rapidly catabolized by many bacteria. Since $S$. flexibilis is very flexible and can readily move through media containing up to $1.5 \%$ (wt/vol) agar, it is logical to speculate that in nature $S$. flexibilis, in comparison to other bacteria, could easily move within sediments to those areas most favorable for its growth.

A comparison of the properties of $S$. flexibilis PFR-1 with those of the bacteria described in Bergey's Manual of Determinative Bacteriology (3) indicates that this organism cannot be identified with any existing bacterial genus or species. Generally, very motile, flexible bacteria are usually considered members of the order Myxobacterales, the order Spirochaetales, or the family Spirillaceae. On the bases of morphology and the absence of gliding motility, $S$. flexibilis can be excluded from the first two taxa. The salient characteristics of Spirillaceae $(11,12,19)$ include (i) helical shape, (ii) bipolar flagella fascicles without lateral flagella, and (iii) intracellular polyhydroxybutyrate granules. Under all growth conditions used, $S$. flexibilis PFR-1 was invariably rod shaped and never displayed any degree of helical morphology. Although a rodshaped spirillum has been described (12), it possesses many other characteristics which permit its inclusion with the Spirillaceae. However, the absence in $S$. flexibilis of all three of the abovementioned and other characteristics of Spirillaceae indicate that this organism cannot be placed in the family Spirillaceae. Since strain PFR-1 cannot be identified as belonging to any known bacterial species, it is justifiable that this flexible, thin organism be considered as belonging to a new species in a new genus, but assignment, of these new taxa to an order or a family is not feasible at this time. Descriptions of these new taxa follow.

Serpens gen. nov. (Ser'pens. L. Fem. n. Serpens snake, serpent).

Rod-shaped, gram-negative, nonsporeforming cells, 0.3 to $0.4 \mu \mathrm{m}$ wide by 8 to $12 \mu \mathrm{m}$ long, which occur singly. Stationary-growth-phase cells are longer (16 to $25 \mu \mathrm{m}$ ) and often possess spherical protuberances or blebs. Extremely flexible and very motile; rapid serpentine-like movement is commonly displayed in agar gels. Flagella occur in bipolar tufts of 4 to 10 flagella and, in an indeterminate number, over the surface of the cell. Polyhydroxybutyrate granules are not produced.

Surface colonies on 1.8 to $2.0 \%$ (wt/vol) agar media are cream colored, 3 to $6 \mathrm{~mm}$ in diameter, and round with filamentous edges. Only subsurface, spreading colonies occur on media with less than 1.5\% (wt/vol) agar.

Chemoorganotrophic. Metabolism is respiratory, and molecular oxygen serves as the terminal electron acceptor. This organism may possibly prefer microaerophilic conditions, but no growth occurs anaerobically with or without nitrate or sulfate. Carbon and energy sources are mainly restricted to lactate. There is limited growth with acetate or $\alpha$-ketoglutarate and slight or no growth with carbohydrates, fatty acids, or sugar alcohols. Catalase and oxidase are produced.

Casein hydrolysate, peptone, yeast extract, and $\mathrm{NH}_{4} \mathrm{Cl}$ serve as nitrogen sources whereas nitrate and nitrite do not. Some strains may not use $\mathrm{NH}_{4} \mathrm{Cl}$ as a nitrogen source. Ammonia is produced from amino acids. No vitamins are required for growth although both vitamin mixtures and yeast extract stimulate growth.

Temperature for optimal growth: 28 to $33^{\circ} \mathrm{C}$; 
no growth occurs at 10 or $45^{\circ} \mathrm{C}$.

The $\mathrm{G}+\mathrm{C}$ content of the DNA is $65.8 \mathrm{~mol} \%$

(strain PFR-1; buoyant density).

Isolated from pond water-mud slurry.

Type species: $S$. flexibilis.

Serpens flexibilis sp. nov. (flex $\cdot \mathbf{i} \cdot$ bil'is. L. adj. flexibilis flexible, pliant).

The description of this species is the same as that for the genus inasmuch as at the present this is the only species in the genus.

The type strain of $S$. flexibilis is PFR-1. A culture of the type strain has been deposited with the American Type Culture Collection, Rockville, Md., under the number 29606. The description of the type strain is the same as that for the species, the description of which is based on a single strain.

Obviously the species and generic descriptions will have to be modified as additional strains of the species are isolated and described and as additional species are placed in the genus.

\section{ACKNOWLEDGMENTS}

I wish to thank Stanley C. Holt, Linda Thomashow, and David Odelson for assisting with the electron microscopy. I am grateful to the Center for Electron Microscopy (University of Illinois) for use of its facilities and to M. Mandel for determining the $\mathrm{G}+\mathrm{C}$ content of the DNA of $\mathrm{S}$. flexibilis PFR-1. This research was supported in part by a grant from the National Science Foundation (PCM 75-23110).

\section{REPRINT REQUESTS}

Address reprint requests to: Dr. Robert B. Hespell, Microbiology Division, Department of Dairy Science, University of Illinois, Urbana, IL 61801

\section{LITERATURE CITED}

1. Breznak, J. A., and E. Canale-Parola. 1969. Spirochaeta aurantia, a pigmented facultatively anaerobic spirochete. J. Baceriol. 97:386-395.

2. Breznak, J. A., and E. Canale-Parola. 1975. Morphology and physiology of Spirochaeta aurantia strains isolated from aquatic habitats. Arch. Microbiol. 105: $1-12$.

3. Buchanan, R. E., and N. E. Gibbons (ed.). 1974. Bergey's manual of determinative bacteriology, 8 th ed. The Williams and Wilkins Co., Baltimore.
4. Canale-Parola, E., S. L. Rosenthal, and D. G. Kupfer. 1966. Morphological and physiological characteristics of Spirillum gracile sp. n. Antonie van Leeuwenhoek J. Microbiol. Serol. 32:113-124.

5. Carls, R. A., and R. S. Hanson. 1971. Isolation and characterization of tricarboxylic acid cycle mutants of Bacillus subtilis. J. Bacteriol. 106:243-248.

6. Conn, H. J., M. W. Jennison, and O. B. Weeks. 1957. Routine tests for the identification of bacteria, $p$. 140-168. In M. J. Pelczar and H. J. Conn (ed.), Manual of microbiological methods. McGraw-Hill, New York.

7. DePamphilis, M. L., and J. Adler. 1971. Fine structure and isolation of the hook-basal body complex of flagella from Escherichia coli and Bacillus subtilis. J. Bacteriol. 105:384-395.

8. Hespell, R. B., and E. Canale-Parola. 1970. Spirochaeta litoralis sp. n., a strictly anaerobic marine spirochete. Arch. Mikrobiol. 74:1-18.

9. Hespell, R. B., and E. Canale-Parola. 1970. Carbohydrate metabolism in Spirochaeta stenostrepta. J. Bacteriol. 103:216-226.

10. Hespell, R. B., R. A. Rosson, M. F. Thomashow, and S. C. Rittenberg. 1973. Respiration of Bdellovibrio bacteriovorus strain 109J and its energy substrate for intraperiplasmic growth. J. Bacteriol. 113:1280-1288.

11. Hylemon, P. B., J. S. Wells, N. R. Kreig, and H. W. Jannasch. 1973. The genus Spirillum: a taxonomic study. Int. J. Syst. Bacteriol. 23:340-380.

12. Kreig, N. R. 1976 . Biology of the chemoheterotrophic spirilla. Bacteriol. Rev. 40:55-115.

13. Mandel, M. 1966. Deoxyribonucleic acid base composition in the genus Pseudomonas. J. Gen. Microbiol. 43:273-292.

14. Marmur, J. 1961. A procedure for the isolation of deoxyribonucleic acid from micro-organisms. J. Mol. Biol. 3:208-218.

15. Salanitro, J. P., and P. A. Muirhead. 1975. Quantitative method for the gas chromatographic analysis of shortchain monocarboxylic and dicarboxylic acids in fermentation media. Appl. Microbiol. 29:374-381.

16. Schleifer, K. H., and O. Kandler. 1972. Peptidoglycan types of bacterial cell walls and their taxonomic implications. Bacteriol. Rev. 36:407-477.

17. Silva, M. T., and J. C. F. Sousa. 1973. Ultrastructure of the cell wall and cytoplasmic membrane of gramnegative bacteria with different fixation techniques. J. Bacteriol. 113:953-962.

18. Umbreit, W. W., R. H. Burris, and J. F. Stauffer. 1964. Manometric techniques, 4th ed. Burgess Publishing Co., Minneapolis.

19. Williams, M. A., and S. C. Rittenberg. 1957. A taxonomic study of the genus Spirillum Ehrenberg. Int. Bull. Bacteriol. Nomen. Taxon. 7:49-110. 